\title{
Uji Perasan Bonggol Nanas (Ananas comosus (L) Merr) Sebagai Antikoagulan
}

\author{
Farah Fajarna ${ }^{1}$, Safridha Kemala Putri ${ }^{1}$, Sulaiha ${ }^{2}$ \\ ${ }^{1}$ Prodi Teknologi Laboratorium Medik Poltekkes Kemenkes Aceh \\ ${ }^{2}$ Alumni Prodi Teknologi Laboratorium Medik Poltekkes Kemenkes Aceh \\ Email. ffarah1976@gmail.com,
}

\begin{abstract}
Abstrak
Telah dilakukan penelitian dengan judul "Uji Perasan Bonggol Nanas (Ananas comosus (L) Merr) Sebagai Antikoagulan”. Buah nanas (Ananas comosus (L) Merr) mengandung senyawa enzim bromelin yang dapat menghambat agregasi trombosit, membantu mencerna protein, antibakteri dan mempunyai aktivitas fibrinolitik. Penelitian ini bertujuan untuk mengetahui apakah perasan bonggol nanas (Ananas comosus (L) Merr) dapat digunakan sebagai anti pembekuan darah (antikoagulan). Metode penelitian yang digunakan adalah metode eksperimen. Penelitian ini dilakukan di Laboratorium Patologi Akademi Analis Kesehatan (AAK) Pemerintah Aceh pada tanggal 19 dan 20 Februari 2018. Dalam penelitian ini yang menjadi populasi adalah buah nanas (Ananas comosus (L) Merr), sedangkan sampelnya adalah air perasan bonggol nanas (Ananas comosus (L) Merr) dengan konsentrasi 100\% yang diambil dari 50 gram bonggol buah nanas (Ananas comosus (L) Merr). Hasil penelitian menunjukkan bahwa $1 \mathrm{ml}$ darah yang dicampurkan dengan $100 \mu 1$ dan $150 \mu \mathrm{l}$ perasan bonggol nanas masih mengalami pembekuan, $1 \mathrm{ml}$ darah yang dicampurkan dengan $200 \mu \mathrm{l}-400 \mu \mathrm{l}$ perasan bonggol nanas hanya terdapat bekuan halus sedangkan $1 \mathrm{ml}$ darah yang dicampurkan dengan $450 \mu \mathrm{l}-500 \mu \mathrm{l}$ perasan bonggol nanas sama sekali tidak terbentuk pembekuan darah. Maka berdasarkan hasil penelitian yang telah dilakukan dapat disimpulkan bahwa perasan bonggol nanas (Ananas comosus (L) Merr) dapat menghambat pembekuan darah namun tidak bisa digunakan sebagai antikoagulan untuk pemeriksaan laboratorium.
\end{abstract}

Kata Kunci : Bonggol Nanas, Enzim Bromelin, Antikoagulan, Darah

\section{PENDAHULUAN}

Laboratorium klinik adalah laboratorium kesehatan yang melaksanakan pelayanan pemeriksaan spesimen klinik dengan tujuan mendapatkan informasi tentang kesehatan perorangan terutama yang dapat menunjang upaya diagnosis penyakit, penyembuhan penyakit, dan pemulihan kesehatan.

Laboratorium klinik berdasarkan jenis pelayanannya terbagi menjadi 2, yaitu laboratorium klinik umum dan laboratorium klinik khusus. Laboratorium klinik umum merupakan laboratorium yang melaksanakan pelayanan pemeriksaan spesimen klinik di bidang hematologi, kimia klinik, mikrobiologi klinik, parasitologi klinik, dan imunologi klinik. Laboratorium klinik khusus merupakan laboratorium yang melaksanakan pelayanan pemeriksaan spesimen klinik pada 1 (satu) bidang pemeriksaan khusus dengan kemampuan tertentu (PERMENKES NO.411/MENKES/PER/III/2010 tentang laboratorium klinik).

Dalam menjalankan tugasnya laboratorium klinik menggunakan berbagai spesimen sebagai bahan pemeriksaan salah satunya darah. Darah merupakan suatu 
suspensi partikel dalam suatu larutan koloid cair yang mengandung elektrolit. Komponen cair darah yang disebut plasma terdiri dari $91 \%-92 \%$ air yang berperan sebagai medium transport dan $8 \%-9 \%$ zat padat. Zat padat tersebut antara lain protein-protein seperti albumin, globulin, faktor-faktor pembekuan darah, dan enzim (Price, 2005).

Darah yang digunakan sebagai bahan pemeriksaan terkadang diperlukan darah yang sudah dicampur dengan antikoagulan sebagai anti pembekuan darah. Antikoagulan dipakai untuk menghambat agregasi trombosit. Salah satu antikoagulan yang biasanya digunakan adalah Etilen Diamin Tetra Acetat (EDTA) yang merupakan salah satu zat antikoagulan yang menghambat agregasi trombosit lebih baik dari pada antikoagulan lainnya (Kiswari, 2014). Namun, antikoagulan tersebut dibuat dari bahan kimia dan jika terjadi kehabisan stok atau telah kadaluarsa maka akan menghambat proses pemeriksaan. Oleh karena itu, banyak penelitian yang dilakukan terhadap bahan alami yang mudah didapatkan dan memiliki kandungan zat yang dapat menghambat agregasi trombosit.

Salah satu kandungan bahan alami yang dapat menghambat agregasi trombosit adalah enzim bromelin yang terdapat dalam buah nanas. Enzim ini terdapat dalam semua bagian nanas. Dalimartha (2011) menuliskan bahwa enzim bromelin banyak terdapat di batang dan di bagian tengah buah nanas. Enzim bromelin merupakan kelompok sulfur yang mengandung enzim proteolitik. Bromelin berkhasiat membantu mencerna protein, mengurangi peradangan (antiinflamasi) dan pembengkakan, mengganggu pertumbuhan sel kanker, menghambat agregasi trombosit (platelet), antibakteri dan mempunyai aktivitas fibrinolitik.

\section{Tujuan Penelitian}

Tujuan umum dari penelitian ini adalah menguji perasan bonggol nanas (Ananas comosus (L) Merr) sebagai anti pembekuan darah (antikoagulan).

Tujuan khusus dari penelitian ini adalah untuk mengetahui apakah perasan bonggol nanas (Ananas comosus (L) Merr) dapat digunakan sebagai anti pembekuan darah (antikoagulan).

\section{TINJAUAN KEPUSTAKAAN}

\section{Buah Nanas (Ananas comosus (L) Merr)}

Nanas merupakan tanaman buah yang tumbuh sejak berabad-abad tahun lalu. Nanas diperkirakan bisa masuk ke Indonesia karena nanas dibawa oleh penjajah dari Spanyol dan penjajah dari Portugal pada abad ke-15 (Nugraheni, 2016).

Menurut Samadi (2014) morfologi buah nanas terdiri dari mahkota, tunas mahkota, buah, tunas pangkal buah, tunas tangkai buah, tangkai buah, tunas batang, batang, daun, tunas akar dan akar. Sedangkan anatomi buah nanas terdiri dari mahkota, hati (bonggol), kelenjar madu, pembuluh madu, kulit buah, daging pelindung dan tangkai buah. Nanas (Ananas comosus (L) Merr) mengandung vitamin A, vitamin C, Kalsium, Fosfor, Magnesium, Besi, Natrium, Kalium, dekstrosa, sukrosa, enzim bromelin (Suparni \& Wulandari, 2012). Selain itu, nanas juga mengandung peroksida, asam fosfat, beberapa protease inhibitor dan organik yang mengikat kalsium.

Bromelin termasuk ke dalam golongan sufrihidil yang mengandung enzim proteolitik. Enzim bromelin menghidrolisis protein yang mengandung ikatan peptida menjadi asam amino yang lebih sederhana. Dalam hal ini sisteinendopeptidase secara khusus memotong ikatan peptida pada gugus karbonil seperti yang ditemukan dalam arginin atau asam amino aromatik yaitu fenilalanin atau tirosin (Masri, 2013). 


\section{Darah}

Darah merupakan salah satu jaringan dalam tubuh yang berbentuk cair berwarna merah. Karena sifat darah yang berbeda dengan cairan lain, mengakibatkan darah dapat bergerak dari satu tempat ke tempat lain sehingga dapat menyebar ke berbagai kompartemen tubuh. Darah didistribusikan melalui pembuluh darah dari jantung keseluruh tubuh dan akan kembali lagi menuju jantung (Nugraha, 2015).

Menurut Sherwood L dalam Desmawati (2013) menyatakan bahwa darah adalah kendaraan atau medium untuk transportasi jarak jauh berbagai bahan antara selsel itu sendiri. Plasma adalah suatu cairan kompleks yang berfungsi sebagai medium transportasi untuk zat-zat yang diangkat dalam darah. Sedangkan menurut Price \& Wilson dalam Desmawati (2013) darah adalah suatu suspensi partikel dalam suatu larutan koloid cair yang mengandung elektrolit dan merupakan suatu medium pertukaran antar sel yang terfikasi dalam tubuh dan lingkungan luar. Menurut Nugraha (2015) darah dibentuk dari dua komponen yaitu komponen selular yang sering disebut juga korpuskuli yang terdiri dari sel eritrosit, leukosit dan trombosit serta komponen non-selular berupa cairan yang disebut plasma.

\section{Pembekuan Darah}

Bila darah ditumpahkan maka cepat ia menjadi lekat dan segera mengendap sebagai zat kental berwarna merah. Jeli atau gumpalan itu mengerut dan keluarlah cairan bening berwarna kuning jerami yang disebut serum (Pearce, 2005). Menurut Desmawati (2013) mekanisme pembekuan darah dapat berlangsung secara bertahap sedemikian rupa sehingga salah satu faktor koagulasi diubah menjadi bentuk aktif demikian selanjutnya diakhiri dengan pembentukan fibrin (bekuan).

\section{Antikoagulan}

Menurut Sadikin (2002) antikoagulan adalah senyawa-senyawa yang dapat menghambat pembekuan darah. Antikoagulan ada yang bekerja mengganggu pematangan protein faktor penggumpalan seperti trombin, faktor $\mathrm{V}$ dan faktor VII. Ada pula antikogulan yang bekerja mengikat $\mathrm{Ca}^{2+}$, selain itu ada antikoagulan yang bekerja dengan mengaktifkan antitrombin.

Sedangkan menurut Kiswari (2014), aktivitas zat antikoagulan pada dasarnya adalah dengan mengikat atau mengendapkan ion kalsium $(\mathrm{Ca})$. Ion kalsium adalah salah satu faktor pembekuan (faktor IV), tanpa ion kalsium pembekuan tidak terjadi dan akan menghambat pembentukan trombin. Menurut Kiswari (2014) antikoagulan yang sering digunakan dalam laboratorium yaitu:

1) Kalium Etilen Diamin Tetra Acetate ( $\mathrm{K}_{3}$ EDTA)

2) Natrium sitrat (Sodium Citrate)

3) Oksalat

4) Heparin

5) Asam Sitrat Dekstrosa (ACD)

6) Sodium Polianetol Sulfonat (SPS)

\section{METODOLOGI PENELITIAN}

Tempat dan Waktu Penelitian

Penelitian ini di lakukan di Laboratorium Patologi Akademi Analis Kesehatan (AAK) Pemerintah Aceh. Penelitian ini dilakukan pada tanggal 19 sampai dengan 20 Februari 2018. 


\section{Populasi dan Sampel}

Populasi pada penelitian ini adalah buah nanas (Ananas comosus (L) Merr). Sampel pada penelitian ini adalah air perasan bonggol nanas (Ananas comosus (L) Merr) dengan konsentrasi 100\% yang diambil dari 50 gram bonggol buah nanas (Ananas comosus (L) Merr).

\section{Instrumen Penelitian}

Alat-alat yang digunakan yaitu: pisau, tatakan/talenan, Beaker glass, timbangan, blender, saringan, labu Erlenmeyer, corong gelas, sendok plastik, tabung reaksi, rak tabung, mikropipet, spidol permanen. Bahan-bahan yang digunakan yaitu: kain kasa, kapas, alkohol 70\%, spuit, tourniquet, kertas saring.

\section{Prosedur Kerja Pembuatan Perasan Bonggol Nanas}

Menurut Makalew, Nangoy \& Wowor (2016) proses pembuatan perasan bonggol nanas dilakukan dengan tahapan sebagai berikut:

1. Buah nanas dipotong dan dipisahkan bonggol dari bagian lainnya menggunakan pisau.

2. Bonggol nanas dipotong keci-kecil dan dihaluskan.

3. Jus yang dihasilkan kemudian diperas dan disaring.

\section{Prosedur Kerja Pengambilan Darah Vena}

Menurut Gandasoebrata (2010) proses pengambilan darah vena dilakukan sebagai berikut:

1. Dicari bagian pembuluh darah vena pada lengan yang akan ditusuk, dibersihkan dengan alkohol 70\% dan dibiarkan sampai kering.

2. Tepat diatas percabangan vena mediana cubiti dipasang ikatan pembendung pada lengan atas dan pasien diminta mengepal agar vena terlihat jelas.

3. Kulit diatas vena ditegangkan dengan jari-jari tangan kiri supaya vena tidak dapat bergerak.

4. Kulit ditusuk dengan jarum spuit dengan tangan kanan sampai ujung jarum masuk kedalam lumen vena.

5. Setelah itu pembendung dilepaskan dan penghisap spuit ditarik secara perlahan.

6. Kapas alkohol ditaruh diatas jarum lalu spuit dan jarum itu dicabut.

7. Pasien diminta untuk menekan selama beberapa menit.

8. Diangkat jarum dari spuit dan darah dialirkan melalui dinding tabung ke dalam tabung yang tersedia.

\section{Prosedur Kerja Pembuatan Kontrol Dengan Antikoagulan EDTA}

Kiswari (2014) menjelaskan prosedur kerja penambahan antikoagulan dalam darah sebagai berikut:

1) Disiapkan tabung reaksi yang sudah diisi dengan antikoagulan EDTA 1-1,5 mg.

2) Dipindahkan jarum suntik dari spuit dengan memutarnya menggunakan penutup jarum dan dialirkan darah ke dalam tabung.

3) Darah dan antikoagulan dicampur dengan hati-hati sehingga tercampur sempurna. 
4) Dalam proses pencampuran jangan menggoyangkan terlalu kuat karena dapat menyebabkan hemolisis.

Prosedur Kerja Pengujian Perasan Bonggol Nanas (Ananas comosus (L) Merr) sebagai Antikoagulan

1. Perasan bonggol nanas dimasukkan ke dalam tabung reaksi sebanyak $100 \mu 1,150$ $\mu 1,200 \mu 1,250 \mu 1,300 \mu 1,350 \mu 1,400 \mu 1,450 \mu 1$ dan $500 \mu 1$.

2. Dimasukkan $1 \mathrm{ml}$ darah ke dalam maing-masing tabung yang berisi perasan bonggol nanas $100 \mu 1,150 \mu 1,200 \mu 1,250 \mu 1,300 \mu 1,350 \mu 1,400 \mu 1,450 \mu 1$ dan $500 \mu 1$.

3. Dihomogenkan secara perlahan dan diamati.

\section{Pengumpulan Data}

Penelitian ini dilakukan dengan mengumpulkan data dari hasil pengujian perasan bonggol nanas (Ananas comosus (L) Merr) sebagai antikoagulan.

\section{Analisa Data}

Analisa data dilakukan secara kualitatif dengan melihat pada ukuran berapa mikro liter $(\mu l)$ perasan bonggol nanas bisa menghambat penggumpalan darah secara sempurna.

\section{Penyajian Data}

Hasil dari penelitian ini akan disajikan dalam bentuk tabulasi.

\section{HASIL PENELITIAN DAN PEMBAHASAN \\ Hasil Penelitian}

Setelah dilakukan penelitian uji perasan bonggol nanas (Ananas comosus (L) Merr) sebagai antikoagulan yang dilakukan pada tanggal 19 sampai dengan 20 Februari 2018, maka diperoleh hasil sebagai berikut:

Tabel Hasil pengamatan uji perasan bonggol nanas (Ananas comosus (L) Merr) sebagai antikoagulan.

\begin{tabular}{|c|c|c|c|}
\hline $\begin{array}{c}\text { Nomor } \\
\text { Tabung }\end{array}$ & $\begin{array}{c}\text { Volume Perasan } \\
\text { Bonggol Nanas } \\
\text { Konsentrasi } 100 \%\end{array}$ & $\begin{array}{c}\text { Volume } \\
\text { Darah }\end{array}$ & Hasil Pengamatan \\
\hline 1. & $100 \mu 1$ & $1 \mathrm{ml}$ & Darah membeku \\
\hline 2. & $150 \mu 1$ & $1 \mathrm{ml}$ & Darah membeku \\
\hline 3. & $200 \mu 1$ & $1 \mathrm{ml}$ & Darah tidak membeku (terdapat bekuan halus) \\
\hline 4. & $250 \mu 1$ & $1 \mathrm{ml}$ & Darah tidak membeku (terdapat bekuan halus) \\
\hline 5. & $300 \mu 1$ & $1 \mathrm{ml}$ & Darah tidak membeku (terdapat bekuan halus) \\
\hline 6. & $350 \mu 1$ & $1 \mathrm{ml}$ & Darah tidak membeku (terdapat bekuan halus) \\
\hline 7. & $400 \mu 1$ & $1 \mathrm{ml}$ & Darah tidak membeku (terdapat bekuan halus) \\
\hline 8. & $450 \mu 1$ & $1 \mathrm{ml}$ & Darah tidak membeku \\
\hline 9. & $500 \mu 1$ & $1 \mathrm{ml}$ & Darah tidak membeku \\
\hline
\end{tabular}




\section{Pembahasan}

Penelitian ini dilakukan untuk menguji perasan bonggol nanas (Ananas comosus (L) Merr) sebagai antikoagulan. Menurut Sadikin (2002) antikoagulan adalah senyawa-senyawa yang dapat menghambat pembekuan darah. Antikoagulan ada yang bekerja mengganggu pematangan protein faktor penggumpalan seperti thrombin, faktor V dan faktor VII.

Suparni dan Wulandari (2012) menyatakan bahwa buah nanas mengandung vitamin A, vitamin C, Kalsium, Fosfor, Magnesium, Besi, Natrium, Kalium, dekstrosa, sukrosa dan enzim bromelin. Menurut Masri (2013) enzim bromelin dapat menghidrolisis protein yang mengandung ikatan peptida menjadi asam amino yang lebih sederhana. Nugraheni (2016) menyatakan bahwa enzim bromelin banyak terdapat di batang dan di bagian tengah buah nanas (bonggol).

Pada penelitian ini dilakukan pencampuran perasan bonggol nanas (Ananas comosus (L) Merr) konsentrasi 100\% dengan $1 \mathrm{ml}$ darah. Perasan bonggol nanas (Ananas comosus (L) Merr) tersebut dimasukkan dengan volume berbeda untuk setiap tabung pengujian yaitu dimulai dari volume $100 \mu 1,150 \mu 1,200 \mu 1,250 \mu 1,300 \mu 1$, $350 \mu 1,400 \mu 1,450 \mu 1$ sampai $500 \mu 1$. Pada penelitian ini juga digunakan darah yang dicampur dengan antikoagulan EDTA sebagai kontrol positif.

Berdasarkan hasil penelitian yang telah dilakukan dapat diketahui bahwa $1 \mathrm{ml}$ darah yang dicampurkan dengan $100 \mu \mathrm{l}$ dan $150 \mu \mathrm{l}$ masih mengalami pembekuan, 1 $\mathrm{ml}$ darah yang dicampurkan dengan $200 \mu \mathrm{l}-400 \mu \mathrm{l}$ hanya terdapat bekuan halus sedangkan $1 \mathrm{ml}$ darah yang dicampurkan dengan $450 \mu \mathrm{l}-500 \mu \mathrm{l}$ sama sekali tidak terbentuk pembekuan darah. Terhambatnya pembekuan darah pada penelitian ini disebabkan karena adanya enzim bromelin di dalam perasan bonggol nanas. Sebelumnya telah diketahui bahwa enzim bromelin dapat menghidrolisis protein menjadi asam amino yang lebih sederhana sehingga enzim bromelin dapat menghidrolisis faktor pembekuan darah yang tersusun dari senyawa protein dan menyebabkan pembekuan darah tidak terjadi.

Pembekuan darah terhambat tergantung dari banyaknya enzim bromelin yang terkandung di dalam perasan bonggol nanas. Dari hasil penelitian diketahui bahwa volume terkecil perasan bonggol nanas (Ananas comosus (L) Merr) yang dapat menghambat pembekuan darah secara optimal adalah $450 \mu 1$. Volume tersebut kurang efektif untuk digunakan sebagai antikogulan alternatif dalam pemeriksaan laboratorium karena dapat terjadi pengenceran yang terlalu besar antara darah dan perasan bonggol nanas yang digunakan sehingga dapat mempengaruhi hasil pemeriksaan. Pengenceran tersebut terjadi diakibatkan karena banyaknya kandungan air dan senyawa lain yang terdapat dalam perasan bonggol nanas sehingga kerja enzim bromelin untuk menghambat pembekuan darah menjadi terganggu dan terhambat.

Meskipun perasan bonggol nanas tidak efektif digunakan sebagai antikoagulan di laboratorium dan belum ditemukan penelitian tentang manfaat perasaan bonggol nanas dengan konsentrasi $100 \%$ untuk kesehatan maupun keperluan lainnya, namun karena banyaknya kandungan enzim bromelin dalam nanas sehingga sangat bermanfaat untuk keperluan lainnya yaitu dapat menghambat penggumpalan trombosit serta mempunyai aktifitas fibrinolitik menyebabkan berkurangnya thrombus dan arteriosklerosis berkurang sehingga jantung koroner dan stoke berkurang (Dalimatha, 2016). Selain itu, Nugraheni (2016) menuliskan bahwa terdapat penelitian yang menunjukkan jika mengonsumsi nanas dapat membantu melawan rasa sakit 
gangguan arthritis atau radang sendi, mengurangi inflamasi atau peradangan, mengatasi gangguan pencernaan dan membantu mengobati cacingan. Bromelin yang dimiliki nanas juga memiliki kemampuan untuk membantu menyeimbangkan dan menetralkan cairan tubuh, dapat merangsang sekresi hormon pankreas sehingga bermanfaat bagi pencernaan. Enzim bromelin yang disekresi dari batang nanas dapat mengurangi pertumbuhan tumor.

Wulandari (2016) juga menuliskan manfaat lainnya dari enzim bomelin yaitu dapat mempercepat penyembuhan luka,mengobati luka bakar, dapat melunakkan daging serta sering juga digunakan sebagai alat kontrasepsi Keluarga Berencana. Nanas juga memiliki kemampuan megurangi keluarnya asam lambung yang berlebihan, sebagai anti diuretik serta dapat membersihkan jaringan kulit yang mati. Sedangkan Fang \& Jun (2002) menuliskan bahwa mengonsumsi nanas potong secara langsung atau dengan meminum perasan atau jus nanas dapat mengobati pencernaan yang tidak beres disertai muntah dan perut bengkak.

\section{Kesimpulan}

Berdasarkan hasil penelitian uji perasan bonggol nanas (Ananas comosus (L) Merr) sebagai antikoagulan dengan konsentrasi perasan $100 \%$ yang dicampurkan 1 $\mathrm{ml}$ darah menunjukkan bahwa volume terkecil perasan bonggol nanas (Ananas comosus (L) Merr) dapat menghambat pembekuan darah adalah $450 \mu$ l. Maka berdasarkan hasil penelitian dapat disimpulkan bahwa perasan bonggol nanas (Ananas comosus (L) Merr) dapat menghambat pembekuan darah namun tidak bisa digunakan sebagai antikoagulan untuk pemeriksaan laboratorium karena dapat terjadi pengenceran sehingga mempengaruhi hasil pemeriksaan.

\section{DAFTAR PUSTAKA}

Agromedia, R. (2009). Buku Pintar Budi Daya Tanaman Buah Unggul Indonesia.

Penyunting, M. Topan Nixon. Cetakan I. Jakarta: Agromedia Pustaka.

Bakta, I. M. (2012). Hematologi Klinik Ringkas. Jakarta : EGC.

Dalimartha, S. (2011). Khasiat Buah \& Sayur. Cetakan II. Jakarta: Penebar Swadaya.

Desmawati. (2013). Sistem Hematologi \& Imunologi: Asuhan Keperawatan

Umum dan Maternitas Dilengkapi Dengan Latihan Soal-Soal. Jakarta: Penerbit In Media.

Fang, D .Y., \& Jun, L. C. 2002. Terapi Buah. Penerjemah: Sujono, A. L. Jakarta: Prestasi Pustaka.

Gandasoebrata, R. (2010). Penuntun Laboratorium Klinik. Cetakan Keenam belas, Jakarta: Dian Rakyat.

Kiswari, R. (2014). Hematologi \& Transfusi. Jakarta: Penerbit Erlangga.

Makalew, M. A. J, Nangoy, E \& Wowor, P, M. (2016). Uji Efek Antibakteri Air Perasan Daging Buah Nanas (Ananas comosus (L) Merr) Terhadap Bakteri Klebsialla pneumonia. Jurnal e-Biomedik, 4(1).

Masri, M. (2013). Isolasi dan Pengukuran Aktivitas Enzim Bromelin Dari Ekstrak Kasar Batang Nanas (Ananas comosus) Pada Variasi pH. Jurnal Biologi \& Education, halaman 7-8. journal.uinalauddin.ac.id/index.php/biogenesis/article/download/478/455. Di akses 16 Juli 2017.

Menteri Kesehatan Republik Indonesia. (2010). Peraturan Menteri Keshatan Republik 
Indonesia Nomor 411/MENKES/PER/III/2010 Tentang Laboratorium Klinik. Jakarta. http://ngada.org/menkes411-2010.htm. Di akses 16 Juli 2017.

Notoatmodjo, S. (2010). Metodologi Penelitian Kesehatan. Jakarta: Ineka Cipta.

Nugraha, G. (2015). Panduan Pemeriksaan Laboratorium Hematologi Dasar. Jakarta: TIM.

Nugraheni. (2016). Sehat Tanpa Obat Dengan Nanas. Yogyakarta: ANDI.

Pearce, E. (2005). Anatomi dan Fisiologi Untuk Paramedis. Cetakan kedua puluh tujuh. Penerjemah: Handoyo, Sri Yuliani. Jakarta: PT Gramedia Utama.

Price, S. A., \& Wilson, L. M. (2005). Patofisiologi: Konsep Klinis ProsesProses Penyakit. Edisi 6. Penerjemah: Brahm, U, dkk. Jakarta: EGC.

Sadikin, M. H. (2002). Biokimia Darah. Jakarta: Widya Medika.

Samadi, B. (2014). Panen Untung dari Budi Daya Nanas Sistem Organik. Yogyakarta:Lily Publisher.

Suparni, I \& Wulandari, A. (2012). HERBAL NUSANTARA: 1001 Ramuan Tradisional Asli Indonesia. Edisi I. Yogyakarta: Rapha Publishing.

Tarwoto, Aryani, R, \& Wartonah. (2009). Anatomi dan Fisiologi Untuk Mahasiswa Keperawatan. Jakarta: TIM.

Wulandari. (2016). Cara Gampang Budidaya Nanas. Cetakan I. Jawa Barat: Villam media. 